\title{
Serum protein expression in Equine Glandular Gastric Disease (EGGD) induced by phenylbutazone
}

\author{
Parichart TESENA ${ }^{1,2)}$, Yodying YINGCHUTRAKUL ${ }^{3)}$, Sittiruk ROYTRAKUL ${ }^{3)}$, \\ Tuempong WONGTAWAN ${ }^{4)}$ and Kris ANGKANAPORN ${ }^{5) *}$ \\ ${ }^{1)}$ Graduate Program in Animal Physiology, Department of Veterinary Physiology, Faculty of Veterinary Science, \\ Chulalongkorn University, Bangkok 10330, Thailand \\ 2) Department of Clinical Science and Public Health, Faculty of Veterinary Science, Mahidol University, Salaya, \\ Puttamonthon, Nakhon Pathom 73170, Thailand \\ 3)Proteomics Research Laboratory, Genome Technology Research Unit, National Center for Genetics \\ Engineering and Biotechnology, Pathum Thani 12120, Thailand \\ 4)Department of Pre-clinical and Applied Animal Science, Faculty of Veterinary Science, Mahidol University, \\ Salaya, Puttamonthon, Nakhon Pathom 73170, Thailand \\ ${ }^{5)}$ Department of Veterinary Physiology, Faculty of Veterinary Science, Chulalongkorn University, Bangkok \\ 10330, Thailand
}

J. Vet. Med. Sci.

81(3): 418-424, 2019

doi: 10.1292/jvms.18-0679

Received: 17 November 2018 Accepted: 14 January 2019 Published online in J-STAGE: 23 January 2019
ABSTRACT. Equine Glandular Gastric Disease (EGGD) is a common disease in sport horses. This disease might be associated with usage of nonsteroidal anti-inflammatory drugs (NSAIDs) for treating inflammatory diseases. Although gastroscopy has been an effective method for diagnosis, but a less invasive, and inexpensive method is preferred. This study used proteomic technology to identify candidate serum proteins that might be used as markers of NSAIDs induced EGGD. Five Thoroughbred horses were given high doses of NSAID, phenylbutazone to treat lameness. The experiment was divided into three periods: (i) Pre-EGGD period, (ii) during EGGD period, and (iii) Post-EGGD period. Gastroscopy were used to diagnose EGGD, serum was collected to perform gel electrophoresis (1D SDS-PAGE) and mass spectrometry (LC-MS) in order to identify serum proteins in each group. The candidate serum proteins were computationally predicted for the interaction between phenylbutazone and proteins, tissue specific expression, and association to gastric ulceration. After EGGD induction, all horses showed clinical signs of colic with marked congestion and erosion appearing in the mucosa of the glandular stomach whereas no change was observed in the mucosa of non-glandular stomach. Our proteomic results identified 14 proteins that might be used as EGGD markers. These proteins were highly expressed in the glandular stomach and some proteins were associated with phenylbutazone or ulcer development. However, confirmation of these candidate marker proteins is required with specific antibodies in the larger horse population before they can be considered for application in the field.

KEY WORDS: EGGD, horse, marker, NSAIDs, proteomics

Equine Gastric Ulcer Syndrome (EGUS) is a very common ailment that is described by inflammation, erosion and ulceration of the horse stomach [26]. EGUS can be divided into two disease entities based where the lesions occur in the stomach: Equine Squamous Gastric Disease (ESGD), with ulceration occurring in the non-glandular region of the stomach; Equine Glandular Gastric Disease (EGGD), with ulceration occurring in the glandular region of the stomach and is equivalent to peptic ulcer in humans [39]. Unlike ESGD, EGGD appears to be an emerging disease (specifically in sport horses) about with little is known and that has had limited research. The possible risk factors for EGGD include breed, management, stress [29], and non-steroid antiinflammatory drugs (NSAIDs) [32]. It is believed that NSAIDs can induce gastric damage by inhibition of COX enzymes leading to decreased concentration of mucosal prostaglandins (PGs), which play an important role in gastric mucosa protection [20, 28]. In addition, most NSAIDs can enter gastric cells easily, be trapped and accumulate within cells and begin to injure gastric cells by changing intracellular $\mathrm{pH}$ and damaging mitochondria leading to cell death $[5,28]$.

The current gold standard to diagnose and monitor EGGD is to use gastroscopy, but this technique is unsuitable for disease screening as it is time consuming and requires expensive equipment. Screening tests such as commercial blood fecal test [33] and 
Table 1. Animal details

\begin{tabular}{ccccl}
\hline Horse & Age (year) & Gender & Body weight $(\mathrm{kg})$ & \multicolumn{1}{c}{ Illness } \\
\hline 1 & 12 & Gelding & 468 & Arthritis and hoof cracks \\
2 & 8 & Gelding & 436 & Arthritis and hoof cracks \\
3 & 10 & Gelding & 486 & Arthritis and hoof cracks \\
4 & 6 & Gelding & 460 & Myositis on left gluteal muscle \\
5 & 9 & Stallion & 450 & Arthritis and hoof cracks \\
\hline
\end{tabular}

sucrose permeability test [12], are available, but their specificity is low, and they cannot distinguish between ESGD and EGGD. Currently, there is no diagnosis marker for EGGD, but attempts have been made to identify serum protein markers for the diagnosis of ESGD. Taharaguchi et al. [41] reported the presence of the isoform of alpha 1-antitrypsin as a candidate marker in foals and Poltep et al. [34] suggested keratin 1, 6A, and 18 as candidate markers for adult horses.

In this initial study, the objective was to use proteomic technology to identify serum proteins that might be used as EGGD markers. With the longer term aim of developing candidate markers into a rapid and inexpensive screening test for widespread equine use.

\section{MATERIALS AND METHODS}

The experimental protocol was approved by Institution Animal Care and Use Committee (IACUC) of the Faculty of Veterinary Science, Chulalongkorn University (permission No. 1531079).

\section{Animals}

Five Thoroughbred horses, aged between 8-12 years and weighing 436-486 kg, were used in this study. They had history of a lameness but no gastrointestinal signs, normal appetite, normal fecal appearance, and no record of any other sickness for more than 2 years. During the experiment, clinical signs were observed, and physical examination was performed twice a day (morning and evening). Animal details are shown in Table 1.

\section{Experimental design}

The experiment was divided into 3 periods; pre-EGGD period, EGGD period (after disease induction when gastric ulcers and colic signs appear), and post-EGGD periods (after antiulcer therapy for a month). The "pre-EGGD period' was the period before horses were given phenylbutazone to induce EGGD. Horses were given the drug orally at $10.5 \mathrm{mg} / \mathrm{kg}$ body weight (BW) twice daily for the first 2 days [30] and then decreased to $5.25 \mathrm{mg} / \mathrm{kg} \mathrm{BW}$ twice daily until the horses showed clinical signs of colic, at this stage called "during EGGD". After the horses showed colic signs, gastroscopy was performed to observe gastric mucosa, and administration of phenylbutazone ceased. The horses were thereafter treated orally with antiulcer drugs, omeprazole at $4 \mathrm{mg} / \mathrm{kg}$ BW once daily and sucralfate at $12 \mathrm{mg} / \mathrm{kg}$ BW twice daily for a month [2, 39], with this period called "post-EGGD".

\section{Gastroscopy and blood collection procedure}

Feed was withdrawn for 15-18 hr and water supply was removed for 3-5 hr prior to gastroscopy according to a standard recommendation [31]. The horses were then injected with $0.5-1 \mathrm{mg} / \mathrm{kg}$ BW xylazine hydrochloride intravenously and a 3-m video gastroscope (Huger AGVE 2100A2, Shanghai, China) was used to examine the gastric mucosa. Gastric lesion for both glandular and non-glandular stomach was described according to European College of Equine Internal Medicine Consensus Statement [39].

Blood samples $(10 \mathrm{~m} l)$ were collected from the jugular vein of each horse into a plain tube after the gastroscopy, and sera were separated and kept in $-80^{\circ} \mathrm{C}$ freezer until proteomic analysis. Blood was collected in each of the three experimental periods.

\section{One-dimensional sodium dodecyl sulfate polyacrylamide gel electrophoresis (1D-SDS-PAGE) analyses}

The serum samples were diluted with acetone to a $2: 1(\mathrm{v} / \mathrm{v})$ ratio, and then centrifuged at $10,000 \times \mathrm{g}$ for $10 \mathrm{~min}$. The pellet was suspended in lysis buffer $(0.25 \%$ (w/v) SDS, $50 \mathrm{mM}$ Tris- $\mathrm{HCl} \mathrm{pH} 9.0)$ and the total protein concentration was determined according to the method of Lowry [22]. Fifty micrograms of total serum protein from each of the five horses at the same sampling period were pooled, and then $50 \mu \mathrm{g}$ of the mixed serum protein was added to the SDS-PAGE loading buffer, heated at $95^{\circ} \mathrm{C}$ for $10 \mathrm{~min}$, and resolved by SDS-PAGE (12.5\% (w/v) acrylamide resolving gel) according to Laemmli [19]. The protein molecular weight was determined by comparison to co-resolved Thermo Scientific Spectra ${ }^{\mathrm{TM}}$ Multicolor Broad Range Protein Ladders after Coomassie R250 staining [37]. The gel was then de-stained and imaged by GS-710 calibrated imaging densitometer (Bio-Rad, Hercules, CA, U.S.A.) before all protein bands were cut into slices, the bands excised from the gel and in-gel digestion using trypsin following a standard protocol [36].

\section{Liquid Chromatography/Mass spectrometry/Mass spectrometry (LC-MS/MS) analysis and identification of proteins}

An Ultimate 3000 LC system (Thermo Scientific Dionex, Waltham, MA, U.S.A.) on-line coupled to an impact II (Bruker Daltonics, Billerica, MA, U.S.A.) tandem mass spectrometer was used with a Captive Spray ion source (Bruker Daltonics). The 
hydrolysate samples were loaded onto a $100 \mu \mathrm{m} \times 50 \mathrm{~mm}$ PepSwift Monolithic ${ }^{\circledR}$ Nano column (Bruker Daltonics) and chromatographic separation was performed using a linear $1-45 \%(\mathrm{v} / \mathrm{v})$ gradient of $80 \%(\mathrm{v} / \mathrm{v})$ acetonitrile in $0.1 \%(\mathrm{v} / \mathrm{v})$ formic acid at a flow rate of $1.0 \mu \mathrm{l} / \mathrm{min}$ for $10 \mathrm{~min}$. The total time for each LC-MS/MS run was about $20 \mathrm{~min}$. The LC-MS/MS data were acquired using a data-dependent auto-MS/MS dynamic method selecting the most abundant precursor ions in $3 \mathrm{sec}$ cycle for fragmentation. The mass range of the MS scan was set to extend from m/z 150 to 2,200.

\section{Data analysis}

For protein quantitation, DeCyder MS Differential Analysis software (Thermo Fisher Scientific) was used. The LC-MS/MS data were converted to mzXML data using the CompassXport software (GE Healthcare, Bangkok, Thailand). The PepDetect module was used for automated peptide detection, charge state assignments and quantitation based on the peptide ions signal intensities in the MS mode. The analysed MS/MS data from DeCyder MS were then submitted for database searching using the Mascot software (Matrix Science) to search the Equus caballus database for protein identification. Database interrogation was: enzyme (trypsin), fixed modification (carbamidomethyl (C)), variable modifications (oxidation (M)), mass values (monoisotopic), protein mass (unrestricted), peptide mass tolerance (1.2 Da), fragment mass tolerance $( \pm 0.6 \mathrm{Da})$, peptide charge state $(1+, 2+$ and $3+)$, $\max$ missed cleavages (3) and instrument ESI-QUAD-TOF. Proteins considered as identified had at least one peptide with an individual mascot score corresponding to $P<0.05$.

To identify candidate markers, we searched for the connection of identified proteins to gastric ulceration, their specific expression in the glandular stomach and the interaction to phenylbutazone. Tissue specific expression of proteins was predicted using public databases UniProt, NCBI, and the protein data atlas from horse and other species. The association of protein to gastric ulceration was identified by using research databases such as PubMed, Google Scholar, Scopus and Web of Science. The interactions between phenylbutazone and protein expression were analysed using STITCH online software, version 5.0 [40].
Table 2. The lesion grade of ulceration in non-glandular stomach according to EGUS council [3]

\begin{tabular}{cccc}
\hline \multirow{2}{*}{ Horse } & \multicolumn{3}{c}{ Ulcer lesion grade } \\
\cline { 2 - 4 } & Pre-EGGD & During EGGD & Post-EGGD \\
\hline 1 & 0 & I & 0 \\
2 & 0 & I & 0 \\
3 & I & II & 0 \\
4 & I & II & I \\
5 & I & III & I \\
\hline
\end{tabular}

$0=$ Normal, $\mathrm{I}=$ Mucosa is intact, but there are areas of hyperkeratosis, $\mathrm{II}=$ Small, single or multifocal lesions, III=Large single or extensive superficial lesions.

$\begin{array}{llll}1 & 2 & 3 & M\end{array}$

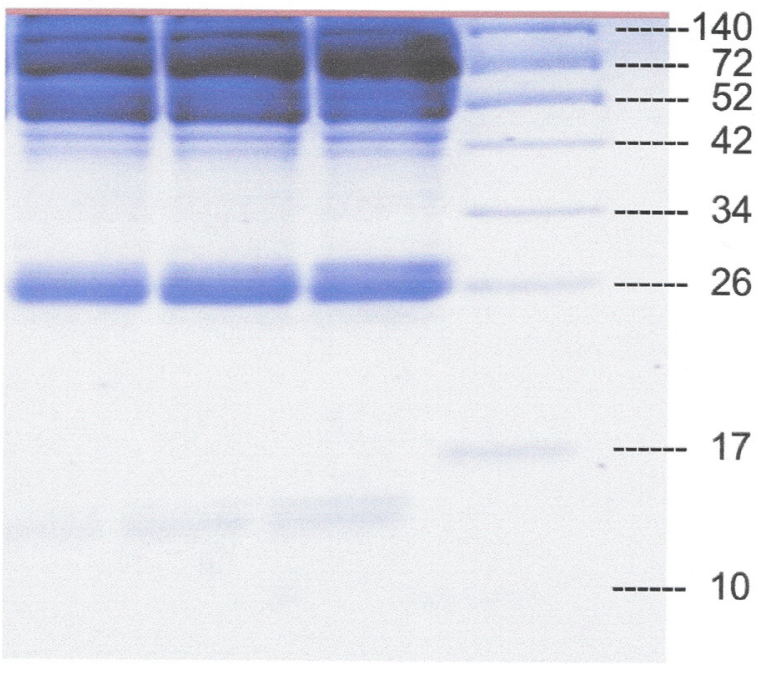

Fig. 1. 1D-SDS-PAGE of the pooled equine serum from the five horses in the three different treatment periods. $\mathrm{L} 1=$ pre-EGGD, L2 = during EGGD and L3 = post-EGGD. $\mathrm{M}=$ Molecular weight markers $(\mathrm{kDa})$.

\section{RESULTS}

At the pre-EGGD period, all horses had lameness problems but were normal in terms of gastrointestinal signs. During the EGGD period, all horses had colic signs within 3 days after induction, the signs included severe abdominal pain, circling, pawing, sweating, distress, peculiar postures (sitting, stretching), absence or decreased gut sound, anorexia (both eating and drinking), tachycardia, hyperpnea and congested mucous membrane. After treatment with the anti-ulceration drug for a month (post-EGGD period), the colic signs disappeared.

\section{Gastric lesion}

During the pre-EGGD period, horses had no EGGD lesions, but during the EGGD period, lesions were evident in the glandular stomach and was found to be diffuse severe hyperemia, with one horse (no. 5) developing gastric hemorrhage. After treatment (post-EGGD period), the glandular mucosa became intact in all horses.

The lesion grade of ulceration in the non-glandular stomach is shown in Table 2. For non-glandular stomach, all horses in the pre-EGGD period had a lesion grade between 0 -I. The lesion grade increased during the EGGD period. For the post-EGGD period, the lesion grade was reduced or became normal in all horses.

\section{Serum protein analysis by $1 D-S D S-P A G E$}

The SDS-PAGE analysis of the serum proteins in the three experimental periods revealed that there was a different expression level of protein bands with an apparent molecular weight of $\sim 15$ and $\sim 26$ among the three periods (Fig. 1). However, we decided to cut all protein bands and performed LC-MS/MS analysis in order to analyze all possible candidate proteins. 
Table 3. Identified proteins that interact with phenylbutazone found in serum of EGGD horse

\begin{tabular}{llllrc}
\hline Protein name & \multicolumn{1}{c}{ Function } & Accession no & Peptide sequence & ID score & $\begin{array}{r}\text { Relative } \\
\text { abundance }\end{array}$ \\
\hline PTGR2 & Prostaglandin metabolism and inflammation & gi|545202385 & CLFLTSELGFDAAINYK & 2.39 & 18.69 \\
UGT1A1 & Drug metabolism and inflammation & gi|545204572 & DNPSTTRR & 12.42 & 14.12 \\
PTBP1 & mRNA metabolism and inflammation & gi|953857639 & AGPNPVLQAPSTRGK & 0.52 & 15.51 \\
\hline
\end{tabular}

Table 4. Identified mitochondrial proteins found in serum of EGGD horse

\begin{tabular}{|c|c|c|c|c|c|}
\hline Protein name & Function & Accession no & Peptide sequence & ID score & $\begin{array}{c}\text { Relative } \\
\text { abundance }\end{array}$ \\
\hline MIA40 & Transported protein & gi|149728408 & QSPGGTICPPGTTGQTEHRAVQGK & 5.84 & 16.13 \\
\hline ACSM3 & Ligase & gi|953871140 & CIITNEVLAPAVDAVASKCENLHSK & 2.25 & 16.07 \\
\hline HSCB & Co-chaperone & gi $\mid 953860426$ & AFERGQSMEDAR & 7.61 & 16.55 \\
\hline DNAJA3 & Modulates apoptotic signal transduction & gi| 953871543 & WLLVAVGTPRLPAAAGRGARPPR & 6.46 & 15.49 \\
\hline ECI1 & Lipid metabolism & gi|545184019 & GSGLRPRGAGRFASGGRDGGTEGER & 7.42 & 14.48 \\
\hline AGXT2 & Inhibitor of nitric-oxide (NO) synthase & gi|953882954 & VIFFTNSGSEANDLAMLMAR & 9.49 & 18.07 \\
\hline AK2 & Cellular energy homeostasis & gi|545208219 & QAEMLDDLMEKRK & 1.39 & 19.64 \\
\hline AK4 & Cellular energy homeostasis & gi $\mid 953854155$ & LRQYKDVAKPVIELYKSR & 4.11 & 18.50 \\
\hline MRPL2 & Protein translation & gi|149732209 & WIIATENMQAGDIILNSDHIGRMAVAAR & 4.21 & 20.29 \\
\hline
\end{tabular}

Table 5. Predicted highly expressed proteins appeared during EGGD

\begin{tabular}{llllcc}
\hline Protein & \multicolumn{1}{c}{ Functions } & Accession no & Peptide & $\begin{array}{c}\text { ID score } \\
\begin{array}{c}\text { Relative } \\
\text { abundance }\end{array}\end{array}$ \\
\hline FCGBP & Mucus formation and mucosa protection & gi|953864464 & CSCSASAGLTCQAAGCLLGRVCDVQSGVR & 6.53 & 15.32 \\
HDC & Gastric acid secretion and inflammation & gi|194206665 & SPRALADEMCLPSVNGAGDDSAQTRK & 4.48 & 15.81 \\
\hline
\end{tabular}

\section{Identification of differentially expressed serum proteins by LC-MS/MS analysis}

In total, 2,078 identified proteins were expressed in the three different periods, plus in addition an extra 38, 40 and 51 different proteins were expressed only in the pre-EGGD, during EGGD and post-EGGD periods, respectively. There was an overlapped expression of 131, 210 and 134 proteins between the pre- and during-EGGD, during- and post-EGGD and pre- and post-EGGD periods, respectively.

\section{Data analysis}

Analysis from STITCH software showed that 3 identified proteins were associated with phenylbutazone (Table 3); they were prostaglandin reductase 2 (PTGR2) and UDP-N-acetylhexosamine pyrophosphorylase-like protein 1 (UGT1A1), which found during and post EGGD while polypyrimidine tract-binding protein 1 (PTBP1) was found only during the EGGD period.

By manual observation, 3 mitochondrial proteins that were only found during EGGD (Table 4), were mitochondrial intermembrane space import and assembly protein 40 (MIA40), acyl-coenzyme A synthetase mitochondrial isoform X1 (ACSM3), iron-sulfur cluster co-chaperone protein HscB, mitochondrial isoform X4 (HSCB). Six proteins found during EGGD and post EGGD (Table 4), were DNAJ homolog subfamily A member 3, mitochondrial isoform X3 (DNAJA3), enoyl-CoA delta isomerase 1, mitochondrial (ECI1), alanine-glyoxylate aminotransferase 2, mitochondrial isoform X2 (AGXT2), adenylate kinase 2, mitochondrial isoform X2 (AK2), adenylate kinase 4, mitochondrial isoform X1 (AK4), and 39S ribosomal protein L2, mitochondrial (MRPL2).

From public database, 2 proteins were found during EGGD and post EGGD that were highly predictively expressed in glandular stomach and associated with gastric ulceration (Table 5). The proteins were IgGFc-binding protein (FCGBP) and histidine decarboxylase (HDC).

\section{DISCUSSION}

In the present study, 14 proteins that might be used as EGGD markers were identified. Three proteins were identified that may interact and bind with phenylbutazone, PTGR2, UGT1A1, and PTBP1 [40]. PTGR2 is a highly expressed enzyme in the stomach, and has a specific domain that can directly bind to phenylbutazone [25]. PTGR2 is involved in gastric inflammation and cancer as well as the metabolism of prostaglandin E2 (PGE2) [8, 45]. It is the most effective prostaglandins (PG) to protect the gastric mucosa by maintaining mucosal integrity and modulating the various functions of the gastrointestinal tract [42]. Binding 
of PTGR2 to phenylbutazone may cause the reduction of enzyme activity and affects the metabolism of PGE2 causing imbalance of PGE2 in the gastric mucosa [45]. UGT1A1 is an important enzyme for drug metabolism, as it can neutralize and eliminate NSAIDs by glucuronidation [18]. Moreover, UGT1A1 can be found in the normal stomach, but its upregulation is related to severe gastric inflammatory disease such as cancer [7]. PTBP, an important enzyme for mRNA metabolism and transport, can be found in the normal stomach [9]. However, its expression increases during inflammation and development of gastric cancer [13, 38]. Phenylbutazone indirectly interacts with PTBP1 via $\mathrm{H}_{2} \mathrm{O}_{2}$ activity induced by phenylbutazone $[4,40]$. Taken together, the presence/ increase of phenylbutazone in EGGD may stimulate the expression of PTGR2, UGT1A1, and PTBP1 in the gastric mucosa of the horse and these proteins may leak into the blood circulation through injured gastric mucosa.

We used high doses of phenylbutazone for two days together with conventional doses for other days to induce EGGD, resulting in all of experimental horses displayed colic signs and EGGD within 3 days after administration. The results are in accordance with many studies which used a high dose strategy to induce EGGD ([23, 24, 27, 30]. Although it is quite clear that high doses of NSAIDs can cause EGGD, the potential of NSAIDs to cause EGGD under a clinical dose regimen is unclear. Andrew et al. [3] reported that a clinical dose of phenylbutazone (approximately $2.6 \mathrm{mg} / \mathrm{kg} / \mathrm{day}$ ) did not induce gastric ulceration when administered for 2 weeks whereas Pedersen et al. [32] used a higher recommended dose (4.4 mg/kg twice a day) for a week and caused EGGD in all horses.

It is well established that NSAIDs affect the glandular mucosa and may cause gastric ulcers [6, 21, 30, 43]. After oral administration, phenylbutazone may accumulate in the gastric mucosal cells and affect mitochondrial functions by decreasing ATP production, activating permeability transition pores, and then releasing cytochrome c into the cytosol resulting in cell apoptosis [5, 28]. Therefore, these mitochondrial released proteins found in this study could be potential proteins for use as NSAIDs induced EGGD markers.

FCGBP and HDC are specifically highly expressed in the glandular stomach and strongly associated with gastric ulceration. FCGBP is highly expressed in mucous neck cells and involved in the formation of mucus that protects the gastric mucosa [15]. NSAIDs may reduce mucus and FCGBP production/secretion via the PG pathway [1] but the presence of FCGBP in EGGD horses may result from a protein leakage through the gastric injury to blood circulation. Conversely, HDC is an enzyme that can cause gastric ulceration by converting histidine to histamine, both HDC and histamine play vital roles in many inflammation diseases including gastric ulceration [44]. It is known that phenylbutazone is able to stimulate the expression of HDC and then increase the cellular level of histamine in mast cells and enterochromaffin-like cells of the gastric mucosa [11, 14, 35]. The high concentrations of histamine can cause hypersecretion of hydrochloric acid from parietal cell of the equine glandular stomach and other species resulting in gastric ulceration $[11,16]$.

We can rule out right dorsal colitis (RDC) [10] affecting the horses in this study from the clinical signs of profuse diarrhea and colic considering the completed blood count (CBC) and blood serum chemistry. All horses had normal packed cell volume (PCV), total protein, albumin and calcium. In addition, renal ischemia and renal papillary necrosis have been reported to precipitate colic [17], but all horses were given an intravenous fluid to maintain renal perfusion throughout the research period, thus, it was unlikely that a renal disorder caused colic.

In conclusion, 14 proteins were identified in this study as potential candidate markers for NSAIDs induced EGGD. All proteins were highly expressed in the glandular stomach and associated with gastric ulceration. Many of them are mitochondrial proteins that are released from apoptotic gastric cells while some proteins directly interact with NSAIDs. All of the identified proteins may leak into the blood circulation during gastric inflammation induced by NSAIDs.

In this study we showed that proteomics and bioinformatics are effective tools for identifying protein markers, but the confirmation of candidate proteins with specific antibodies in the larger horse population is required and further development is needed before the EGGD markers can be applied in the field.

CONFLICTS OF INTEREST. The authors declare no conflict of interest.

ACKNOWLEDGMENTS. This project was supported by Research Scholarships, CU Graduate School Thesis Grant, Graduate School, Chulalongkorn University, Faculty of Veterinary Science Mahidol University, Faculty of Veterinary Science Chulalongkorn University, and Proteomics Research Laboratory, Genome Technology Research Unit, National Center for Genetics Engineering and Biotechnology, Faculty of Veterinary Science, Mahidol University. The authors thank Professor Kasuo KATOH under the support of Rachadaphiseksomphote Endowment Fund 2018, for proof reading of the manuscript. In addition, the English editing assistance of Dr. Robert BUTCHER, Chulalongkorn University, is appreciated.

\section{REFERENCES}

1. Aihara, E., Engevik, K. A. and Montrose, M. H. 2017. Trefoil factor peptides and gastrointestinal function. Annu. Rev. Physiol. 79: 357-380. [Medline] [CrossRef]

2. Andrew, F., Bernard, W., Byars, D., Cohen, N., Divers, T., MacAllister, C., Merritt, A., Murray, M., Orsini, J., Snyder, J. and Vatistas, N. 1999. Recommendations for the diagnosis and treatment of equine gastric ulcer syndrome (EGUS). The Equine Gastric Ulcer Council. Equine Vet. Educ. 11: 262-272. [CrossRef]

3. Andrews, F. M., Reinemeyer, C. R. and Longhofer, S. L. 2009. Effects of top-dress formulations of suxibuzone and phenylbutazone on development of gastric ulcers in horses. Vet. Ther. 10: 113-120. [Medline]

4. Aranzales, J., Andrade, B. and Alves, G. 2014. Orally administered phenylbutazone causes oxidative stress in the equine gastric mucosa. J. Vet. 
Pharmacol. Ther. 38: 1-8. [Medline]

5. Brand, M. D., Affourtit, C., Esteves, T. C., Green, K., Lambert, A. J., Miwa, S., Pakay, J. L. and Parker, N. 2004. Mitochondrial superoxide: production, biological effects, and activation of uncoupling proteins. Free Radic. Biol. Med. 37: 755-767. [Medline] [CrossRef]

6. Carrick, J. B., Papich, M. G., Middleton, D. M., Naylor, J. M. and Townsend, H. G. 1989. Clinical and pathological effects of flunixin meglumine administration to neonatal foals. Can. J. Vet. Res. 53: 195-201. [Medline]

7. Cengiz, B., Yumrutas, O., Bozgeyik, E., Borazan, E., Igci, Y. Z., Bozgeyik, I. and Oztuzcu, S. 2015. Differential expression of the UGT1A family of genes in stomach cancer tissues. Tumour Biol. 36: 5831-5837. [Medline] [CrossRef]

8. Chang, E. Y., Tsai, S. H., Shun, C. T., Hee, S. W., Chang, Y. C., Tsai, Y. C., Tsai, J. S., Chen, H. J., Chou, J. W., Lin, S. Y. and Chuang, L. M, 2012. Prostaglandin reductase 2 modulates ROS-mediated cell death and tumor transformation of gastric cancer cells and is associated with higher mortality in gastric cancer patients. Am. J. Pathol. 181: 1316-1326. [Medline] [CrossRef]

9. Fagerberg, L., Hallström, B. M., Oksvold, P., Kampf, C., Djureinovic, D., Odeberg, J., Habuka, M., Tahmasebpoor, S., Danielsson, A., Edlund, K., Asplund, A., Sjöstedt, E., Lundberg, E., Szigyarto, C. A., Skogs, M., Takanen, J. O., Berling, H., Tegel, H., Mulder, J., Nilsson, P., Schwenk, J. M., Lindskog, C., Danielsson, F., Mardinoglu, A., Sivertsson, A., von Feilitzen, K., Forsberg, M., Zwahlen, M., Olsson, I., Navani, S., Huss, M., Nielsen, J., Ponten, F. and Uhlén, M. 2014. Analysis of the human tissue-specific expression by genome-wide integration of transcriptomics and antibody-based proteomics. Mol. Cell. Proteomics 13: 397-406. [Medline] [CrossRef]

10. Galvin, N., Dillon, H. and McGovern, F. 2004. Right dorsal colitis in the horse: minireview and reports on three cases in Ireland. Ir. Vet. J. 57: 467-473. [Medline] [CrossRef]

11. Håkanson, R. and Sundler, F. 1991. Histamine-producing cells in the stomach and their role in the regulation of acid secretion. Scand. J. Gastroenterol. Suppl. 180: 88-94. [Medline] [CrossRef]

12. Hewetson, M., Sykes, B. W., Hallowell, G. D. and Tulamo, R. M. 2017. Diagnostic accuracy of blood sucrose as a screening test for equine gastric ulcer syndrome (EGUS) in adult horses. Acta Vet. Scand. 59: 15. [Medline] [CrossRef]

13. Jiao, H., Dong, P., Yan, L., Yang, Z., Lv, X., Li, Q., Zong, X., Fan, J., Fu, X., Liu, X. and Xiao, R. 2016. TGF- $\beta 1$ Induces polypyrimidine tractbinding protein to alter fibroblasts proliferation and fibronectin deposition in keloid. Sci. Rep. 6: 38033. [Medline] [CrossRef]

14. Kennedy, L., Hodges, K., Meng, F., Alpini, G. and Francis, H. 2012. Histamine and histamine receptor regulation of gastrointestinal cancers. Transl. Gastrointest. Cancer 1: 215-227. [Medline]

15. Kim, Y. S. and Ho, S. B. 2010. Intestinal goblet cells and mucins in health and disease: recent insights and progress. Curr. Gastroenterol. Rep. 12: 319-330. [Medline] [CrossRef]

16. Kitchen, D. L., Merritt, A. M. and Burrow, J. A. 1998. Histamine-induced gastric acid secretion in horses. Am. J. Vet. Res. 59: $1303-1306$. [Medline]

17. Kivett, L., Taintor, J. and Wright, J. 2014. Evaluation of the safety of a combination of oral administration of phenylbutazone and firocoxib in horses. J. Vet. Pharmacol. Ther. 37: 413-416. [Medline] [CrossRef]

18. Kuehl, G. E., Lampe, J. W., Potter, J. D. and Bigler, J. 2005. Glucuronidation of nonsteroidal anti-inflammatory drugs: identifying the enzymes responsible in human liver microsomes. Drug Metab. Dispos. 33: 1027-1035. [Medline] [CrossRef]

19. Laemmli, U. K. 1970. Cleavage of structural proteins during the assembly of the head of bacteriophage T4. Nature 227: 680-685. [Medline] [CrossRef]

20. Laine, L., Takeuchi, K. and Tarnawski, A. 2008. Gastric mucosal defense and cytoprotection: bench to bedside. Gastroenterology 135: 41-60. [Medline] [CrossRef]

21. le Jeune, S. S., Nieto, J. E., Dechant, J. E. and Snyder, J. R. 2009. Prevalence of gastric ulcers in Thoroughbred broodmares in pasture: a preliminary report. Vet. J. 181: 251-255. [Medline] [CrossRef]

22. Lowry, O. H., Rosebrough, N. J., Farr, A. L. and Randall, R. J. 1951. Protein measurement with the Folin phenol reagent. J. Biol. Chem. 193: 265-275. [Medline]

23. MacAllister, C. G., Morgan, S. J., Borne, A. T. and Pollet, R. A. 1993. Comparison of adverse effects of phenylbutazone, flunixin meglumine, and ketoprofen in horses. J. Am. Vet. Med. Assoc. 202: 71-77. [Medline]

24. MacKay, R. J., French, T. W., Nguyen, H. T. and Mayhew, I. G. 1983. Effects of large doses of phenylbutazone administration to horses. Am. J. Vet. Res. 44: 774-780. [Medline]

25. Madej, T., Lanczycki, C. J., Zhang, D., Thiessen, P. A., Geer, R. C., Marchler-Bauer, A. and Bryant, S. H. 2014. MMDB and VAST+: tracking structural similarities between macromolecular complexes. Nucleic Acids Res. 42: D297-D303. [Medline] [CrossRef]

26. Malfertheiner, P., Chan, F. K. and McColl, K. E. 2009. Peptic ulcer disease. Lancet 374: 1449-1461. [Medline] [CrossRef]

27. Martínez Aranzales, J. R., Cândido de Andrade, B. S. and Silveira Alves, G. E. 2015. Orally administered phenylbutazone causes oxidative stress in the equine gastric mucosa. J. Vet. Pharmacol. Ther. 38: 257-264. [Medline] [CrossRef]

28. Matsui, H., Shimokawa, O., Kaneko, T., Nagano, Y., Rai, K. and Hyodo, I. 2011. The pathophysiology of non-steroidal anti-inflammatory drug (NSAID)-induced mucosal injuries in stomach and small intestine. J. Clin. Biochem. Nutr. 48: 107-111. [Medline] [CrossRef]

29. Mönki, J., Hewetson, M. and Virtala, A. M. 2016. Risk factors for equine gastric glandular disease: A case-control study in a finnish referral hospital population. J. Vet. Intern. Med. 30: 1270-1275. [Medline] [CrossRef]

30. Monreal, L., Sabaté, D., Segura, D., Mayós, I. and Homedes, J. 2004. Lower gastric ulcerogenic effect of suxibuzone compared to phenylbutazone when administered orally to horses. Res. Vet. Sci. 76: 145-149. [Medline] [CrossRef]

31. Murray, M. J. 1994. Equine model of inducing ulceration in alimentary squamous epithelial mucosa. Dig. Dis. Sci. 39: 2530-2535. [Medline] [CrossRef]

32. Pedersen, S. K., Cribb, A. E., Read, E. K., French, D. and Banse, H. E. 2018. Phenylbutazone induces equine glandular gastric disease without decreasing prostaglandin $\mathrm{E}_{2}$ concentrations. J. Vet. Pharmacol. Ther. 41: 239-245. [Medline] [CrossRef]

33. Pellerrini, F. 2005. Results of a large-scale necroscopic study of equine colonic ulcers. J. Equine Vet. Sci. 25: 113-117. [CrossRef]

34. Poltep, K., Tesena, P., Yingchutrakul, Y., Taylor, J. and Wongtawan, T. 2018. Optimisation of a serum albumin removal protocol for use in a proteomic study to identify the protein biomarkers for silent gastric ulceration in horses. J. Equine Sci. 29: 53-60. [Medline] [CrossRef]

35. Radwan, A. G. and West, G. B. 1968. The effect of non-steroidal anti-inflammatory drugs on histamine formation in the rat. Br. J. Pharmacol. Chemother. 33: 193-198. [Medline] [CrossRef]

36. Shevchenko, A., Sunyaev, S., Liska, A., Bork, P. and Shevchenko, A. 2003. Nanoelectrospray tandem mass spectrometry and sequence similarity searching for identification of proteins from organisms with unknown genomes. Methods Mol. Biol. 211: 221-234. [Medline]

37. Steinberg, T. H. 2009. Protein gel staining methods: an introduction and overview. Methods Enzymol. 463: 541-563. [Medline] [CrossRef]

38. Sugiyama, T., Taniguchi, K., Matsuhashi, N., Tajirika, T., Futamura, M., Takai, T., Akao, Y. and Yoshida, K. 2016. MiR-133b inhibits growth of human gastric cancer cells by silencing pyruvate kinase muscle-splicer polypyrimidine tract-binding protein 1. Cancer Sci. 107: 1767-1775. 


\section{[Medline] [CrossRef]}

39. Sykes, B. W., Hewetson, M., Hepburn, R. J., Luthersson, N. and Tamzali, Y. 2015. European college of equine internal medicine consensus statement-Equine gastric ulcer syndrome in adult horses. J. Vet. Intern. Med. 29: 1288-1299. [Medline] [CrossRef]

40. Szklarczyk, D., Santos, A., von Mering, C., Jensen, L. J., Bork, P. and Kuhn, M. 2016. STITCH 5: augmenting protein-chemical interaction networks with tissue and affinity data. Nucleic Acids Res. 44 D1: D380-D384. [Medline] [CrossRef]

41. Taharaguchi, S., Nagano, A., Okai, K., Miyasho, T., Kuwano, M., Taniyama, H. and Yokota, H. 2007. Detection of an isoform of alpha(1)antitrypsin in serum samples from foals with gastric ulcers. Vet. Rec. 161: 338-342. [Medline] [CrossRef]

42. Takeuchi, K. and Amagase, K. 2017. Roles of prostaglandin E and EP receptors in mucosal protection and ulcer healing in the gastrointestinal tract. Arch. Dig. Disord 1: 8-16.

43. Vatistas, N. J., Snyder, J. R., Carlson, G., Johnson, B., Arthur, R. M., Thurmond, M., Zhou, H. and Lloyd, K. L. 1999. Cross-sectional study of gastric ulcers of the squamous mucosa in thoroughbred racehorses. Equine Vet. J. Suppl. 29: 34-39. [Medline]

44. Watanabe, T., Yamatodani, A., Maeyama, K. and Wada, H. 1990. Pharmacology of alpha-fluoromethylhistidine, a specific inhibitor of histidine decarboxylase. Trends Pharmacol. Sci. 11: 363-367. [Medline] [CrossRef]

45. Wu, Y. H., Ko, T. P., Guo, R. T., Hu, S. M., Chuang, L. M. and Wang, A. H. 2008. Structural basis for catalytic and inhibitory mechanisms of human prostaglandin reductase PTGR2. Structure 16: 1714-1723. [Medline] [CrossRef] 